University for Business and Technology in Kosovo

UBT Knowledge Center

UBT International Conference

2015 UBT International Conference

Nov 7th, 9:00 AM - 5:00 PM

\title{
Credit Information System in Albania
}

\author{
Valbona Çinaj \\ University of Tirana, bonaribaj@gmail.com \\ Bashkim Ruseti \\ University of Tirana, bruseti@gmail.com
}

Follow this and additional works at: https://knowledgecenter.ubt-uni.net/conference

Part of the Databases and Information Systems Commons, and the Information Security Commons

\section{Recommended Citation}

Çinaj, Valbona and Ruseti, Bashkim, "Credit Information System in Albania" (2015). UBT International Conference. 110.

https://knowledgecenter.ubt-uni.net/conference/2015/all-events/110

This Event is brought to you for free and open access by the Publication and Journals at UBT Knowledge Center. It has been accepted for inclusion in UBT International Conference by an authorized administrator of UBT Knowledge Center. For more information, please contact knowledge.center@ubt-uni.net. 


\title{
Credit Information System in Albania
}

\author{
Valbona Çinaj ${ }^{1}$, Bashkim Ruseti ${ }^{2}$ \\ ${ }^{1,2}$ Faculty of Economic, University of Tirana \\ \{bonaribaj ${ }^{1}$, bruseti $\left.^{2}\right\} @$ gmail.com
}

\begin{abstract}
The booming lending period and many lenders (16 banks and 21 non-bank financial Institutions in Albania) brought about unprecedented competition in credit markets within Albania. Economists usually view lending and competition favorably, but in Albania resulted in a number of unforeseen non-performing loans. Findings report increased problems of borrower over-indebtedness, reduced loan repayment incentives, and growing debts for lenders (Campion 2001; McIntosh and Wydick 2005). The weakening performance of lenders is due in part to the absence of information sharing in these markets. Because growing numbers of lenders (banks and non-bank financial Institutions in Albania) increase the level of asymmetric information between lenders, credit information systems (often called credit reporting bureaus or credit bureaus) can play a crucial role towards improving credit market performance and, in turn, credit access for the poor. Increases in formal sector lending among the poor have created a need for credit information systems that provide potential lenders with borrower information. Improved screening affects from the system causes the level of non-performing loans to decline.
\end{abstract}

In this paper we will present effects of a credit information system to be implemented in Albania.

Keywords: Credit information system, credit score, credit history, non -performing loans.

\section{Introduction}

Most of the assets of the commercial banks include different kinds of deposit which are in fact the debts of the banks during banking and economical activities which are exposed to different forms of risk; the most important kind is Credit Risk (CR) Financial institutions (FIs) are very important in any economy. Their role is similar to that of blood arteries in the human body, because FIs pump financial resources for economic growth from the depositories to where they are required Commercial banks $(\mathrm{CBs})$ are FIs and are key providers of financial information to the economy. They play even a most critical role to emergent economies where borrowers have no access to capital markets There is evidence that well-functioning $\mathrm{CBs}$ accelerate economic growth, while poorly functioning $\mathrm{CBs}$ impede economic progress and exacerbate poverty The magnitude and the level of loss caused by credit risk compared to others is severe to cause bank failures .Lending has been, and still is, the mainstay of banking business, and this is more true to emerging economies where capital markets are not yet well developed. To most of the transition economies, however, particular, lending activities have been controversial and a credit risk matter. This is because business firms on one hand are complaining about lack of credits and the excessively high standards set by banks, while CBs on the other hand have suffered large losses on bad loans. It has been found out that in order to minimize loan losses and so as the CR, it is essential for CBs to have an effective CRM system. Lenders experience positive net revenue impacts from lending if they increase the classification power of their credit scoring systems. If loan officers' subjective assessments of otherwise intangible borrower characteristics contain additional information about a borrower, a lender may improve the default forecast quality of his internal credit scoring systems by utilizing this subjective information. The Basel II regulatory framework requires lenders to use all available information about a borrower, both subjective and non subjective, but at the same time produce consistent and objectified borrower ratings. However, soft information is often laden with inconsistencies due to the lack of comparability of different raters' assessments and the existence of incentives to manipulate the soft rating. The industry trends continued with companies that developing modeling in various applications. Why Credit? The reason is that credit score is so important today in credit process. Facts that after a 20 - 
years history companies are going beyond credit, to build scoring models after this all experience in Developing of Nationalization of banking and credit industries. How do companies try to stay competitive regarding the use of credit? How do companies prepare for increasing regulatory constraints? More diversified use of credit cards, lowering of down payments, increased risk tolerance, Automated Underwriting Systems (AUS). The few opportunities to build credit for Families with low or poor traditional credit. Niche market high potential returns for risky lending. Credit scoring first emerged in the late 1950s to support lending decisions by the credit departments of large retail stores and finance companies. By the end of the 1970s, most of the nation's largest commercial banks, finance companies, and credit card issuers used credit-scoring systems. Over these two decades, the primary use of credit scoring was in evaluating new applications for credit, and creditors used their own experience and data, sometimes with the aid of consultants, to develop the models. Although often available at the time from local credit bureaus (today more commonly referred to as credit-reporting agencies), credit history records were limited in scope and relatively expensive to access. Thus, lenders essentially had no practical way of obtaining the complete credit histories of noncustomers and so could not effectively target them for solicitations on the basis of credit history. By the late 1980s much had changed. Creditors were no longer restricted to the credit histories of their own customers and credit applicants. Rather, lenders could purchase the generic credit history scores of individuals who were not their account holders and, with that data, market consumer credit products tailored to various credit scores to appropriate potential borrowers. The use of credit scoring then spread to additional loan products including home mortgage and small-business lending. Scoring technologies also were applied in new ways, such as in assessments by institutions of whether to purchase individual loans or pools of loans backing securities. Finally, credit-scoring technologies were developed to focus on outcomes beyond credit-risk assessment to include, for example, account profitability and various aspects of account management. As the use of credit scoring was growing, so was the demand for consumer credit and the number of credit instruments offered to finance such activities. Since the early 1900 s, merchants have been offering installment credit to allow customers to stretch out their payments for the purchase of furniture, major appliances, and other large durable goods. Charge cards, such as those offered by oil companies and large retailers, first emerged in the 1950 s, but in most instances full payment were expected within the billing cycle. In the 1960s, retailers began converting their charge cards into credit cards, a credit instrument that allowed the consumer to extend payments over a long period. Generic revolving credit, that is, a re-usable credit account not tied to a specific retailer, dates to the 1950 s with the emergence of the first bankcards, but it begin to flourish with the introduction of credit cards carrying the Visa and MasterCard logos; its usage more than doubled over the 1970s, with much of that growth taking the place of small installment loans The substitution accelerated in the 1980s and 1990s as credit cards--some tied to home equity lines of credit--became widely accepted for the purchase of larger durable goods and as a ready source of funds through cash advance features.

\section{Credit information system, CISs}

CISs (CISs) compile databases that potential lenders can access to help them evaluating a consumer's credit application. They provide information to potential lenders about an applicant's credit record, producing a "credit report" that contains details of the payment and credit history of an individual, financial accounts and the way they have been managed, as well as other information of interest to the credit industry ${ }^{12}$. Reports of CISs help banks stem out misconducts in the banking sector since customers whose credit reports indicate as having been involved in mal practices are subjected to stringent terms and conditions. This is also expected to help banks suppress the levels of NonPerforming Loans while increasing their loan books. Credit information sharing to bank customers, is expected to minimize the problem of information asymmetry in the financial sector. Information asymmetry between banks and borrowers is one of the main contributors to high cost of credit. Thus banks tend to load a risk premium to borrowers because of lack of customer information. This in turn, increases cost of borrowing, meaning repayment of loans escalate which translates to a high level of default.

\footnotetext{
${ }^{12}$ Ferretti, (2006)
} 
The Credit Information Sharing (CIS) apparatus is therefore expected to facilitate the development of information capital to reduce information asymmetry or increase information symmetry and allow cost of credit to decline substantially. It is therefore the Central Bank's expectation that savings arising from the sharing of credit information will translate to lower cost of credit. CISs assist lenders to make faster and more accurate credit decisions. They collect, manage and disseminate customer information to lenders in the form of credit reports. These credit reports will help lenders to decide whether to extend an applicant's loan, credit card overdraft facility or extend any other product, which is reliant on customer's ability to repay at a determined cost.

\section{CISs and Commercial Banks}

In establishing the CISs, what needed to be done first was to convince banks and other financial institutions that if one institution benefits, they all benefit ${ }^{13}$. Customers are then well served and, consequently, receive products that they can afford. Thus there will be fewer loan losses, as the credit institutions loan money responsibly, and then fewer write-offs. In the end, much as with the fraud detection models, savings can be passed on to customers in the form of lower interest rates and better customer service. However, ${ }^{14}$ cautions that although individual banks may find it hard to resist following these trends as a result of market pressure, such an increased homogeneity of business models may augment the vulnerability of the banking sector as a whole.

The individual financial institutions can use the information from the CISs for credit scoring and evaluating client credit worthiness. The process of modeling the variables important in the extension of credit is referred to as credit scoring ${ }^{15}$. Based on statistical analysis of historical data of the customers; certain financial variables are determined to be important in the evaluation process of a credit applicant's financial stability and strength. This analysis produces coefficients which are translated into score weights. Subsequently, information on these important variables is obtained for new bank customers. An overall score for these new applicants is produced by adding the weighted scores which were generated from the responses to the different variables. If this overall score is above a predetermined cut-off point, the loan applicant receives a certain line of credit. If not, the applicant is denied credit.

Commercial Banks in Albania are financial institutions that are authorized by law to receive money from businesses and individuals and lend money to them. They are open to the public and serve individuals, institutions and businesses. They are mainly established with the aim to make a profit by carrying out these activities. Their operations are licensed, supervised and regulated by the central bank.

\section{CISs based on Credit Scoring Models produce credit scores}

A credit score is a numerical expression based on a level analysis of a person's credit files, to represent the creditworthiness of the person. A credit score is primarily based on credit report information typically sourced from CISs. Lenders use credit scores to evaluate the potential risk posed by lending money to consumers and to mitigate losses due to bad debt. Lenders use credit scores to determine who qualifies for a loan, at what interest rate, and what credit limits. Lenders also use credit scores to determine which customers are likely to bring in the most revenue. The use of credit or identity scoring prior to authorizing access or granting credit is an implementation of a trusted system. Credit scoring can be formally defined as a statistical (or quantitative) method that is used to predict the probability that a loan applicant or existing borrower will default or become delinquent ${ }^{16}$. This helps to determine whether credit should be granted to a borrower ${ }^{17}$. Credit scoring can also be defined as a systematic

\footnotetext{
13 Leonard, (1996)

14 Cavelaars and Passenier,(2012)

15 Leonard, (1995)

16 Mester,1997

17 Morrison, 2004
} 
method for evaluating credit risk that provides a consistent analysis of the factors that have been determined to cause or affect the level of risk ${ }^{18}$. The objective of credit scoring is to help credit providers quantify and manage the financial risk involved in providing credit so that they can make better lending decisions quickly and more objectively. In the United States, the Circuit Court has found considerable actuarial evidence that credit scores are a good predictor of risk of loss ${ }^{19}$. Similarly, a recent actuarial study has concluded that credit scores are one of the most powerful predictors of risk; they are also the most accurate predictor of loss seen in a long time ${ }^{20}$.

\subsection{CISs impact borrower repayment and reduce NPLs}

According to ${ }^{21}$ the private sector credit relative to GDP is positively correlated with information sharing in their study of credit market performance and institutional arrangements in 129 countries for the period 1978-2003. Firm-level data suggest that information sharing may indeed have a differential impact on credit availability for different firm types. ${ }^{22}$ Combine cross - sectional firm level data from the 1999 World Business Environment Survey with aggregate data on private and public registries collected in [Miller (2003)]. They find that private credit bureaus are associated with lower perceived financing constraints and a higher share of bank financing (while public credit registries are not), and that these correlations are particularly strong for small and young firms.

To remain competitive, CIS worldwide must not stand on their laurels; they must introduce innovative services to meet the evolving needs of their clients. The impact of credit rating or scoring agencies on financial markets has become one of the most important policy concerns facing the international financial architecture. Ratings indicate a relative credit risk and serve as an important metric by which many investors and regulations measure credit risk.

${ }^{23}$ Find empirical evidence that the lending market would collapse due to credit risk in the absence of information sharing institution and reputational banking. However, their study also showed that establishing CISs encouraged borrowers to repay their loans by allowing lenders to identify borrowers with a good payment history. Their study showed that an information sharing institution positively impacted the credit market in the following ways: Without CISs, borrowers had a tendency to repay loans only when they planned to maintain their current lending relationship. However, in economies with a credit information institution, borrowers had a higher chance of repaying their loans regardless of whether they were planning to continue their current lending relationship or not. Thus, it can be implied that credit sharing institutions, by documenting borrower behavior, can positively impact borrower repayment and reduce NPLs.

The Credit Register in Albania became effective in February 2008. The Regulations require all licensed banks and non-bank financial institutions to share information on Non-Performing Loans (NPLs) through the Credit Register which is part of the Central Bank of Albania (CBA). The role of Credit Register is to collect, collate and process data received from approved sources of information and generate credit reports to be used by lenders.

\section{Conclusions}

CISs services assist in reducing the incidence of non-performing loans. This is made possible through the factors of transaction costs, competitive information sharing, loan loss and delinquency, credit evaluation practices that are enhanced when the CIS services are used.

The implementation of CISs reduces transaction costs and certainly borrowing costs for consumers. Lending institutions in Albania need the CISs services as they enhance their profitability by reducing transaction costs involved in identifying suitable clients that the bank can give loans.

\footnotetext{
18 Fensterstock,2005

19 Johnson-Speck, 2005

20 Miller, 2003.

21 Djankov,(2007)

22 Love and Mylenko (2003)

23 Brown and Zehnder (2007)
} 
Limitations of Credit scoring model should also be noted. One of the major problems that can arise when constructing a credit scoring model is that the model may be built using a biased sample of consumers and customers who have been granted credit ${ }^{24}$. This may occur because applicants (i.e, potential customers) who are rejected will not be included in the data for constructing the model. Hence, the sample will be biased (i.e, different from the general population) as good customers are too heavily represented. The credit scoring model built using this sample may not perform well on the entire population since the data used to build the model is different from the data that the model will be applied to. The second problem that can arise when constructing credit scoring models is the change of patterns over time. The key assumption for any predictive modeling is that the past can predict the future ${ }^{25}$.In credit scoring, this means that the characteristics of past applicants who are subsequently classified as "good" or "bad" creditors can be used to predict the credit status of new applicants. Sometimes, the tendency for the distribution of the characteristics to change over time is so fast that it requires constant refreshing of the credit scoring model to stay relevant.

One of the consequences of credit scoring is the possibility that end-users become so reliant on the technology that they reduce the need for prudent judgment and the need to exercise their knowledge on special cases. In other instances, end-users may unintentionally apply more resources than necessary to work the entire portfolio. This could run into the risk of a self-fulfilling prophecy ${ }^{26}$ In the U.S., a new industry has emerged that is dedicated to help borrowers improve their credit scores by rearranging finance ${ }^{27}$ rather than obeying the simple rule: pay your bills on time and keep your debt low. Such score-polishing actions could potentially distort the patterns of credit default. Despite the limitations of Credit Scoring models highlighted above, there is no doubt that credit scoring will continue to be a major tool in predicting credit risk in consumer lending. It is envisaged that organizations using credit scoring appropriately will gain important strategic advantage and competitive edge over their rivals. From a management perspective, it is worthwhile noting that credit scoring has the following benefits: (1) reduced subjectivity and increased objectivity in risk assessment, (2) increased speed and consistency of risk assessment, (3) possible automation of the risk assessment process, (4) reduced cost of risk assessment, (5) better allocation of resources, (6) better determination of interest rate, loan duration, loan amount, etc., (7) better risk management, (8) better collection/recovery strategies, and (9) possible development of non-traditional markets. It is hoped that this paper can make a contribution to the credit scoring literature.

Data mining has gained widespread attention and increasing popularity in the commercial world. Besides credit scoring, there are other potential data mining applications for businesses. For example, data mining can be used to: (1) perform churn modeling to identify customers who are likely to churn, (2) construct fraud detection models to give early warning signals of possible fraudulent transactions, (3) understand consumers and customers better (e.g., via market basket analysis), (4) segment customers (e.g., via clustering), or (5) construct models to predict the probability of purchasing certain products or services in order to facilitate cross-selling or up-selling. The findings can then be used, say, to prepare mail catalogs, advertisements, promotion campaigns, etc.

\section{Policy Recommendations}

1. The implementation of CISS reduces transaction costs and certainly borrowing costs ultimately the government needs to craft strategies and policies to build CIS in Albania and to oblige relevant institutions to report the consumers data into CIS and lending institutions to get CIS services as this will benefit the populace through reduced interest rates, banks will also benefit from reduced information asymmetry and nonperforming loans.

2. To enhance credit information sharing, information access should be available at low or no cost and this would be facilitated by creating an environment that supports more competitive information sharing both financial and non-financial institutions should be allowed access to credit information reports of borrowers.

\footnotetext{
24 Hand, 2002

25 Berry and Linoff,2000

26 Lucas, 2002

27 Timmons, 2002
} 
3. Central bank should regulate the CISs to give up to date credit information about borrowers which may increase their effectiveness and eventually would reduce information asymmetry, costs and translate into reduced adverse selection.

\section{References}

1. AkSIKe, H. [1973]: Statistical predictor identification, in: Ann. Inst. Statist, Math. 22, 203-217.

2. Altman, E.I. [1968]: Financial Ratios, Discriminate Analysis and the Prediction of Corporate Bankruptcy, in: The Journal of Finance 23 (4), 589-609.

3. Comerce banks in Albania (annual bulletin)

4. A Handbook for Developing Credit score Systems in a Microfinance Context. Prepared by DAI Washington for USAID. October 2006.

5..http://www.microlinks.org/ev_en.php?ID=13456_201\&ID2=DO_TOPIC

6. Chawanda, Rob (OIBM) and Angenita de Rijke (ING).Opportunity International Bank of Malawi: First Step in Credit score. October 2007.

7. http://www.oinetwork.org/documents/First\%20Step\%20in\%20Credit\%20Scoring.doc

8. Mark Schreiner (Microfinance Risk Management) and Dellien, Hans (Women's World Banking). "Credit score, Banks, and Microfinance: Balancing High-Tech With High-Touch.\| December 18, 2005.

9. Canova, L..(2007). the many dimensions of poverty in Albania: Income, wealth and perceptions. 10. EUruçi, I. Gedeshi. (2003). Remittances management in Albania . (2003). CESPI, Center for International Policy Studies. CESPI, 